ISSN: 2454-1362, http://www.jurnal.stie-aas/ijebar

\title{
RISK OF RETURNING DEPOSITO INVESTMENT RESULTS
}

\author{
Djoko Sigit Gunanto \\ Institute of Economic Science (STIE) AAS Surakarta \\ sigit_gunanto@yahoo.co.id
}

\begin{abstract}
The purpose of this study is to understand the risk and return on investment of mudharabah deposits in Islamic banks using the Value at Risk (VaR) approach. The objects in this study are quarterly financial reports of Bank Syariah Mandiri, Bank BRI Syariah, and Bank Muamalat for three years, 2015-2017. VaR analysis results show that the average investment risk of mudharabah deposits for 3 years at Bank Syariah Mandiri was in 2015 amounted to $6.61 \%$ and net return of $-0.53 \%$, in 2016 the risk of $0.14 \%$ and net return of $3.21 \%$, in 2017 the risk is $0.17 \%$ and the net return is $0.32 \%$. BRI Syariah Bank in 2015 was $0.08 \%$ and net return was $4.28 \%$, in 2016 the risk was $0.07 \%$ and the net return was 3.77\%, in 2017 the risk was $0.08 \%$ and the net return was $42.81 \%$. and Bank Muamalat was in 2015 amounted to $0.63 \%$ and a net return of $0.04 \%$, in 2016 a risk of $0.40 \%$ and a net return of $0.08 \%$, in 2017 a risk of $0.14 \%$ and a net return of $0.26 \%$. In addition there are differences in the level of risk and net return on Bank Syariah Mandiri, Bank BRI Syariah, and Bank Muamalat with a significant probability (p-value) for a risk level of 0.005 and a net return of 0.045. From the level of risk and net return for three years, BRI Syariah Bank is a bank that has a prospective value.
\end{abstract}

Keywords: VaR, Risk, Return, Mudharabah Deposit

\section{INTRODUCTION}

Investment is one of the easy ways to produce assets. Investment is a solution for people who are unfamiliar with economics, who might not be able to produce their wealth in economic activities.

According to Hidayati, uncertainty, loss, fear, volality, return, investment are words related to investment risks in banking. Investors who make investments, will get a return as profit (profit). But behind that, investors also bear the risks that must be faced. Risk is not dangerous if the investor has knowledge about risk and can manage the risk. Risk is not something to be avoided but something that must be faced, because as the popular term we use with "high risk high return, low risk low return.
Risk does not have to always be avoided, but it is something that must be faced in an investment. The high level of risk expectations is directly proportional to the expected rate of return. Risk does not have to always be avoided, but something that must be studied, predicted and prepared carefully (Mustofa \& Iin, 2016).

\section{LITERATURE REVIEW}

\section{Mudharabah Deposit Investment}

Mudharabah time deposits represent investment funds placed by customers that do not conflict with sharia principles and withdrawals can be made at a certain time, in accordance with the contractual agreements entered into by the bank and investor customers. Deposits usually have a term of 1 , 3, 6 and 12 months (Tho'in, 2019), (Ismail, 2014) (Nuryanto, 2014). 
Islamic investment products from sharia banking in addition to demand deposits and savings are deposits (Prabowo, 2009). Deposit products because it is shown as an investment tool, then the mudharabah agreement and practice (Tho'in \& Pratiwi, 2019), (Al Anshori, 2009). Through the mudharabah agreement, the profit sharing ratio is determined for both the customer and the Islamic bank itself at the beginning of the agreement. Based on DSN Fatwa No. 3 / DSN-MUI / IV / 2000 in which it is stated that the deposits that are justified in sharia are deposits with mudharabah principle. The depositor's customer is the owner of the fund (shahibul maal) while the Islamic banking is the manager of the fund (mudarib).

The decree of mudharabah deposits in accordance with DSN fatwa No. 3 / DSNMUI / IV / 2000 are as follows:

a. Mudharabah deposit transactions, the depositor's customer as the owner of the funds (shahibul maal) while the Islamic banking as the manager of the funds (mudharib).

b. Fund management by mudarib is carried out in the halal sector, and does not conflict with Islamic principles.

c. Capital must be cash, not accounts receivable.

d. Distribution of profit from mudharabah deposits in the form of profit sharing ratio.

e. Islamic banking as mudarib, in meeting operational costs is taken from the profit ratio that is entitled to Islamic banks.

\section{Risk}

Risk (risk) is a designation for the impossibility of events that have historical precedents and follow a probability distribution, therefore the risk can be estimated theoretically (Prabowo, 2009).

According to the Financial Services Authority Regulation (POJK) No. 18 / POJK.03 / 2016 concerning Application of Risk Management for commercial banks, defining risk is the potential loss due to certain events. Islamic banking is exposed to various risks, such as market risk, credit risk, liquidity risk and so on. So that Islamic banking needs to implement risk management. Risk management is used to identify, measure, monitor and control the risks of all Islamic banking activities.

The concept of uncertainty in the Islamic economy is one of the important points in the process of Islamic risk management. Naturally, in business activities, in this world no one wants a business or investment to suffer losses. Even at the macro level, a country also expects a positive trade balance. The sharia principle regarding returns and risk is $\mathrm{Al}$ ghunmu bil ghurmi, meaning that risk will always accompany any return or return expectation.

The emergence of uncertainty in the Islamic economy is one important point in the process of Islamic risk management. In general, in business activities, no one in the world wants a business or investment to suffer losses.

\section{Return}

According to Fahmi (2011) Returns are profits derived by companies, individuals and institutions from the results of investment policies made. Return is the result obtained from investment. Returns can be either realized returns that have already occurred or expected expectations that have not yet occurred but which are expected to occur in the future (Jogiyanto, 2015).

\section{The concept of Value at Risk (VaR)}

$\mathrm{VaR}$ can be interpreted as the size of the worst losses expected to occur at a certain time horizon under normal market conditions with a certain level of confidence. Many financial institutions and regulators look at VaR as an easy method for understanding and quantifying market risk (Gozali, 2007). 
International Journal of Economics, Business and Accounting Research (IJEBAR)

Peer Reviewed - International Journal

Vol-3, Issue-2, 2019 (IJEBAR)

ISSN: 2454-1362, http://www.jurnal.stie-aas/ijebar

\section{RESEARCH METHODOLOGY}

This research method illustrates a statistical analysis in which to find out the risk weight and net return of mudharabah deposit investments in Islamic commercial banks using the Value at Risk (VaR) approach. This study takes the object in 3 Sharia Commercial Banks, namely Syariah Mandiri Bank, BRI Syariah Bank and Muamalat Bank. The quantitative data in this study consisted of each quarterly Financial Report Publication for the 2015-2017 period. Data includes the amount of mudharabah deposit investment, and the distribution of revenue sharing from mudharabah deposits. Data obtained for risk analysis and mudharabah net return using the VaR method.

\section{RESULTS AND DISCUSSION}

Bank Syariah Mandiri in 2015 had the highest risk level of $6.61 \%$ with the lowest return of $-0.53 \%$. This is according to the quarterly report of Bank Syariah Mandiri in 2015 having 7,229 Trillion. Whereas in June to December an average of 30 trillion. This means that during 2015, Syariah Mandiri banks had high volatility, resulting in high standard deviations so that the level of risk was also high. In 2016, an independent Islamic bank had a risk level of $0.14 \%$ and a return of $3.21 \%$. This can be explained by the independent Islamic banks in 2016 starting to be more stable in providing revenue sharing mudarabah deposits. In 2017 the independent Islamic bank experienced a decline compared to 2016 . In 2017 the risk level rose to $0.17 \%$ and the return dropped to $0.32 \%$.

BRI Syariah Bank in 2015 has a risk level of $0.08 \%$ with a Net Return of $4.28 \%$. In 2016, Bank BRI Syariah had the lowest risk level of $0.07 \%$ and a rate of return of $3.77 \%$. In 2017 Bank BRI Syariah experienced an increase in risk level of $0.08 \%$ with $\mathrm{Net}$ Return increasing by $4.28 \%$ as in 2015 . The low level of risk at Bank BRI Syariah in 2015-2017, means that Bank BRI Syariah on

average stable in providing returns to modharabah deposit investors.

Bank Muamalat in 2015 and 2016 experienced the highest risk compared to 2017 and in 2015-2016 with a low return, this condition was caused by Bank Muamalat in a declining financial condition in recent years. In 2017 Muamalat banks began to stabilize with risks dropping drastically from risks in 2016 from $0.40 \%$ to 2017 with $0.14 \%$ with the highest return of $0.26 \%$.

The movement of the risk level of investment mudharabah deposits at Bank Syariah Mandiri was very high in 2015, and experienced a sharp decline in 2016 and 2017. This is because based on the amount of return of deposits in the first quarter of 2015 Bank Syariah Mandiri, was very high, and declined sharply in the quarter II of 2015. This sharp fluctuation caused Bank Syariah Mandiri to have very high volatility in 2015 . This also meant having high risk during 2015. While BRI sharia banks had the lowest and most stable risk levels of Bank Syariah Mandiri and Bank Muamalat. This is because volatility in Islamic banks tends to be stable so that the standard deviation is low. At Muamalat Bank has high risk in 2015 and 2016. In 2015 and 2016 Bank Muamalat provided mudharabah deposit returns which were quite volatile so that the risk was high. But in 2017 the return tends to be stable so the risk is low at $0.14 \%$.

\section{CONCLUSIONS}

Based on the results of research and discussion of investment risk analysis of mudharabah deposits and returns, it can be concluded that BRI Syariah banks are the most superior in becoming the choice in investing mudharabah deposits. BRI Syariah Bank after measured by Value at Risk has the lowest and most stable risk (VaR Mean) namely, $0.08 \%$ in $2015,0.07 \%$ in 2016 and $0.08 \%$ in 2017. In addition to the low level of risk, BRI Syariah banks had the highest expected rate of return for three years of 
International Journal of Economics, Business and Accounting Research (IJEBAR)

Peer Reviewed - International Journal

Vol-3, Issue-2, 2019 (IJEBAR)

ISSN: 2454-1362, http://www.jurnal.stie-aas/ijebar

observation, namely $4.28 \%$ in $2015,3.77 \%$ in 2016, even in 2017 expected return of $42.81 \%$.

\section{ACKNOWLEDGEMENTS}

With the completion of this research, I would like to thank the Chairperson of STIE AAS Surakarta for granting permission and research facilities.

\section{REFERENCES}

Al Anshori, Abdul ghofur. (2009). Trend Pembentukan Bank Umum Syari'ah Pasca Undang-Undang Nomor 21 Tahun 2008 :Konsep, Regulasi, dan Implementasi. Yogyakarta: BPFEYogyakarta.

Fahmi, Irham. (2011). Analisis Laporan Keuangan. Bandung: Alfabeta

Ghozali, Imam. (2007) Manajemen Risiko Perbankan: Pendekatan Kuantitatif Value at Risk (VaR) (Semarang: Badan Penerbit Universitas Diponegoro

Ismail. (2014). Perbankan Syariah. Edisi Pertama, Cetakan ketiga. Jakarta: Kencana Prenadamedia Grup

Jogiyanto, dkk. (2015). Partial Least Square (PLS) Alternatif Structural Equation Modeling (SEM) dalam Penelitian Bisnis. Ed.1. Yogyakarta: ANDI

Nuryanto, R., Tho'in, M., \& Wardani, H. K. (2014). Rasio Likuiditas, Rasio Solvabilitas, Rasio Rentabilitas Koperasi Jasa Keuangan Syariah Di Jawa Tengah. Jurnal Akuntansi dan Pajak, 15(01).

Prabowo, Yudho. 2009. Analisis Resiko dan Pengembalian Hasil pada Perbankan Syariah: Aplikasi Metode VaR dan RAROC pada Bank Syariah Mandiri. Jurnal La Riba. Vol. 3 No. 1.

Tho'in, M. (2019). The Comparison of Islamic Banking Financial Performance In Indonesia. International Journal of Scientific Research And Education, 7(5).

Tho'in, M., \& Prastiwi, I. E. (2019). An Analysis the Rupiah Exchange Rates Effect Against the American Dollar and Inflation Against the Growth of Islamic Banking Mudharabah Deposits in Indonesia. International Journal of Islamic Business and Economics (IJIBEC), 82-91.

Tho'in, M. (2018). The Effect of Sharia Principles Application and Service Againts Customer Satisfaction of Sharia Financial Services Cooperative In Central Java. International Journal of Economics, Business and Accounting Research (IJEBAR), 2(01).

Ulul Azmi dan Prastiwi, Iin Emy. (2016). Analisis Risiko Investasi Deposito Mudharabah (Studi pada Bank Syariah Mandiri Tahun 2013-2015). Jurnal Ilmiah Ekonomi Islam. Vol.02, No. 02, Sekolah Tinggi Ilmu Ekonomi AAS Surakarta

WA Pratomo \& Ismail. (2006). Islamic bank performance and capital structure. 